\title{
THE HADHRAMI ARABS IN MALAYA BEFORE THE SECOND WORLD WAR
}

\author{
Latifah Abdul Latiff
}

\begin{abstract}
This article highlights the history of the Hadhramis from Hadhramaut, Yemen in the nineteenth and twentieth century in Malaya. The Hadhramis appertained to the Sayyid Alawiyyah and claimed themselves as the descendants of the Prophet Muhammad SAW through his grandson Hussain. In general, Malays respectably looked upon all Arabs particularly the Sadah as they were believed as the inheritors of Islamic preaching. For this article, records from archives as well as academic works were used as reference. According to the archives sources, the Hadhramis who were the majority of the born Arabs or Peranakan Arab of non-Arab mothers managed to do well in their lives even though they were in a small number. They played a significant role in the society and managed to succeed in the economy and political undertaking in Malaya. Thus, being a minority group of immigrants did not hinder the Hadhramis from prospering in Malaya, and many of them were involved in trade and business ventures as well as real estate. In fact, nowadays they have become part of the Malay community and are identified as Malays.
\end{abstract}

\section{Introduction}

Nomadic lifestyle is synonymous with the Arabs. They lived in the desert, moving in groups and engaged in business ventures in the whole Arabian Peninsula. This tradition continued even after the coming 
of Islam. They migrated from one area to another area in the Arab Peninsula looking for business chances while performing their duties as $d \bar{a}^{\prime} i$ spreading Islam. They even migrated to further areas out of the homeland, and sometimes crossed the ocean, passing the Red Sea and the Indian Ocean to Africa, India, and even further eastward to China. On the eastward voyage to China, they would drop in at the Malay Archipelagos while waiting for the monsoon to change and also to look for the supplies of food and fresh water.

Through this contact they intermingled with the Malays and some would stay and build colonies scattered in several countries in the Malay World such as in the East Indies, Philippines, Malaya, Borneo and Sulu. The hardship of living in the desert and struggling at sea made them appreciate life. They would also try to gain control and expand their influence wherever they went. Including using their diplomatic skills, ability to exploit the weak sides of the native character, and their dignity as the respected and esteemed 'ulama' or religious men as well as successful traders, to gain certain degrees of social status in the Malay World. The Arabs, either through a marital bond or influence managed to establish themselves as rulers or having connection with the ruling classes in several places, for example Perlis in Malaya, in Siak Kampar and Jambi in Sumatra, and Pontianak and Kubu in Borneo.

\section{Trade Relation}

The indirect contact between the Arabs and Malays had long been established since time immemorial. The long distance maritime trade between China and the Arab countries that had been established and flourished even before the advent of Islam gave impact to the development of trade in Southeast Asia especially in Malaya. ${ }^{1}$ "The Arabs, controlling the ports of Aden and Sacutra and gifted with an enterprising nature, had been sailing to South-East Asia and China since the immemorial time". ${ }^{2}$ This long distance maritime trade had witnessed the involvement of the Arabs as middle men transporting and supplying commodities from India, and even China crossing the Indian Ocean and the Pacific Ocean. They plied from Arabia to China and vice versa, and became familiar with the Malay Archipelago. The commodities were loaded at Aden before they were distributed and traded in the European markets through Egypt. ${ }^{3}$

The Arabs were masters at the sea controlling the maritime trade with the East and dominating the eastern merchandise and spices until the end of the fifteenth century when Europeans began to discover other routes in the East. Merchandise like pepper, cinnamon and ginger were traded from Aden to Egypt before being marketed in Europe. Moreover, 
the Red Sea and the Persian Gulf also played an important role in the sea trade route between the east and the West Asia. In Hadhramaut itself, the people produced frankincense as the source of income. ${ }^{4}$

With the emergence of Islam in the Arabian Peninsula in the year 610 A.D, the teaching was then widely spread in the whole Arabia and went beyond the region crossing the ocean reaching till Far East, in China and far to the west of Africa in Western Sahara. The Arab Muslim traders were now occupied with the new task as the carriers of the new faith, Islam. The early Arabs' contact with India, which was merely based on trade had changed. Ever since, the Arabs' travel to India was not merely for business purposes but also for doing missionary activities. ${ }^{5}$ The Arabs took the opportunity sailing and crossing the Indian Ocean, passing the Malay Archipelago and voyage up to the Pacific Ocean and arrived in China. Their settlements are to be found in the Western coast of India, in Ceylon, in Malay Archipelago as well as in China. ${ }^{6}$

According to R.B. Serjeant, around the twelfth to the fifteenth century in India, there were colonies of Arabs who lived in several port cities in the coastal areas such as Gujarat, Malabar, Bijapur, and Surat. This makes sense as proposed by Mahayudin Haji Yahaya and other scholars that the coming of "Alawi Sayyids to Southeast Asia in particular to Malaya and Indonesia had occurred in several stages. Most probably the first phase took place around the sixteenth century. ${ }^{7}$ This was followed by the second phase in the seventeenth or the eighteenth century, and the third phase in the nineteenth and early twentieth century. This migration occurred directly and indirectly from Hadhramawt, Yemen with most of them following an indirect course to Southeast Asia. Many of the Hadhramis who came to the island of Singapore, Penang and other Malay states in the eighteenth and nineteenth century were from the East Indies like Java, Palembang, and Aceh. They consisted of religious men, politicians, and traders. ${ }^{8}$

Some of the Arabs who came to this region travelled directly from India and Indo-China before reaching the Malay Archipelago. According to Syed Muhammad Naquib al-Attas around 1290, AlDimashqi recorded about the Arab population known as Al-'Alawiyyin in Champa (Sanf) living in the area or peninsula known as Jazirat al'Alawiyyah. Al-Attas further mentioned that al-Dimashqi could have referred to two separate emigrations of the 'Alawiyyin most probably around the $7^{\text {th }}$ or $8^{\text {th }}$ century Hijri and the second migration occurred in the $13^{\text {th }}$ or early $14^{\text {th }}$ century Hijri. The first migration to the area were by a group of 'Alawis from Makkah and Madinah and most probably from neighbouring cities while the second emigration was also by the 'Alawiyyin or the 'Alawis or Bani 'Alawi particularly from Hadhramaut, Yemen. ${ }^{9}$ Based on this record there was a possibility that the migration 
of the Hadhramis of Sayyid 'Alawiyyah to the Malay Archipelago also took place from Champa, the Jazirat al-'Alawiyyah.

\section{The Origin of Hadhrami Arabs}

The nineteenth century had witnessed the expansion of British colonial rule in Malaya. The opening of Singapore in 1819 as the British base in Southeast Asia to oversee the operation of its long-distance trade in the region had opened lots of opportunities to foreign traders. Singapore has been opened as a free port. The policy introduced by the British had attracted merchants and traders from all over the world, including those Arabs from the Middle East countries to trade in the island. Arabs from Hadhramaut, Yemen were among those traders who travelled to the Malay World to seek fortune in Singapore engaging in business ventures on the island. ${ }^{10}$

The Hadhrami society of Sayyid descent in Malaya claimed that they were descendants of the Prophet Muhammad SAW through his grandson Hussain, one of the sons of Fatimah and Ali. They were also called the descendants of al-Sadah or Sadah (plural of Sayyid). They called themselves as al-Alawiyyin, by connecting their lineage to Sayyid Alawi, grandson of Ahmad bin Isa al-Muhajirir in order to distinguish themselves from other Hadhramis in Hadhramaut. They traced their genealogy back to 'Ali, the great-grandson of Hussin, the sixth generation of Prophet Muhammad SAW's progeny. Ali lived in Basrah and was called Ali al-Qäim Bi-'l Basrah. From Ali's offspring was his great-grandson Ahmad, who was also famously known as Ahmad al-Muhajir, the traveller. He was the son of Isa bin Muhammad bin Ali (al-Qāim Bi-'1 Basrah). Ahmad bin Isa then migrated from Basrah to Hadhramaut, Yemen. The Hadhramis took their clan name from the grandson of Ahmad b. Isa al-Muhajir, Alawi, thus, they called themselves al-Alawiyyin. ${ }^{12}$

The descendants of Alawiyyin emerged in Hadhramawt around 512 A.H./1127 A.D. ${ }^{13}$ In Hadhramaut, their clan extended and they also gained reputable status in the society as the carriers and inheritors of the faith of Islam. The Sadah held religious position and were reputable 'ulama' or religious men in society and very much influential in preserving Shari'ah Law and the teaching of Islam. Tarim was one of the most important centres in their homeland catering to Islamic learning. Many religious scholars were produced in Tarim. They became mufti and $q \bar{a} d \bar{l}$ as well as religious men. The majority of the Hadhramis who were the descendants of Prophet Muhammad SAW lived here. ${ }^{14}$

Being descendants of the Prophet Muhammad S.A.W secured the special place of the Hadhramis in the Malay society. Malays looked 
upon them with respect and deference. Not only for their sacred connection with the Prophet Muhammad S.A.W, but also for their profound knowledge in Islam, as well as their piety. This factor in a way had helped them to be easily accepted by the local Muslims as the successors of the teaching of Prophet Muhammad S.A.W

\section{The lineage of Al-'Alawiyyin clan through the Prophet Muhammad} SAW's grandson, Hussin.
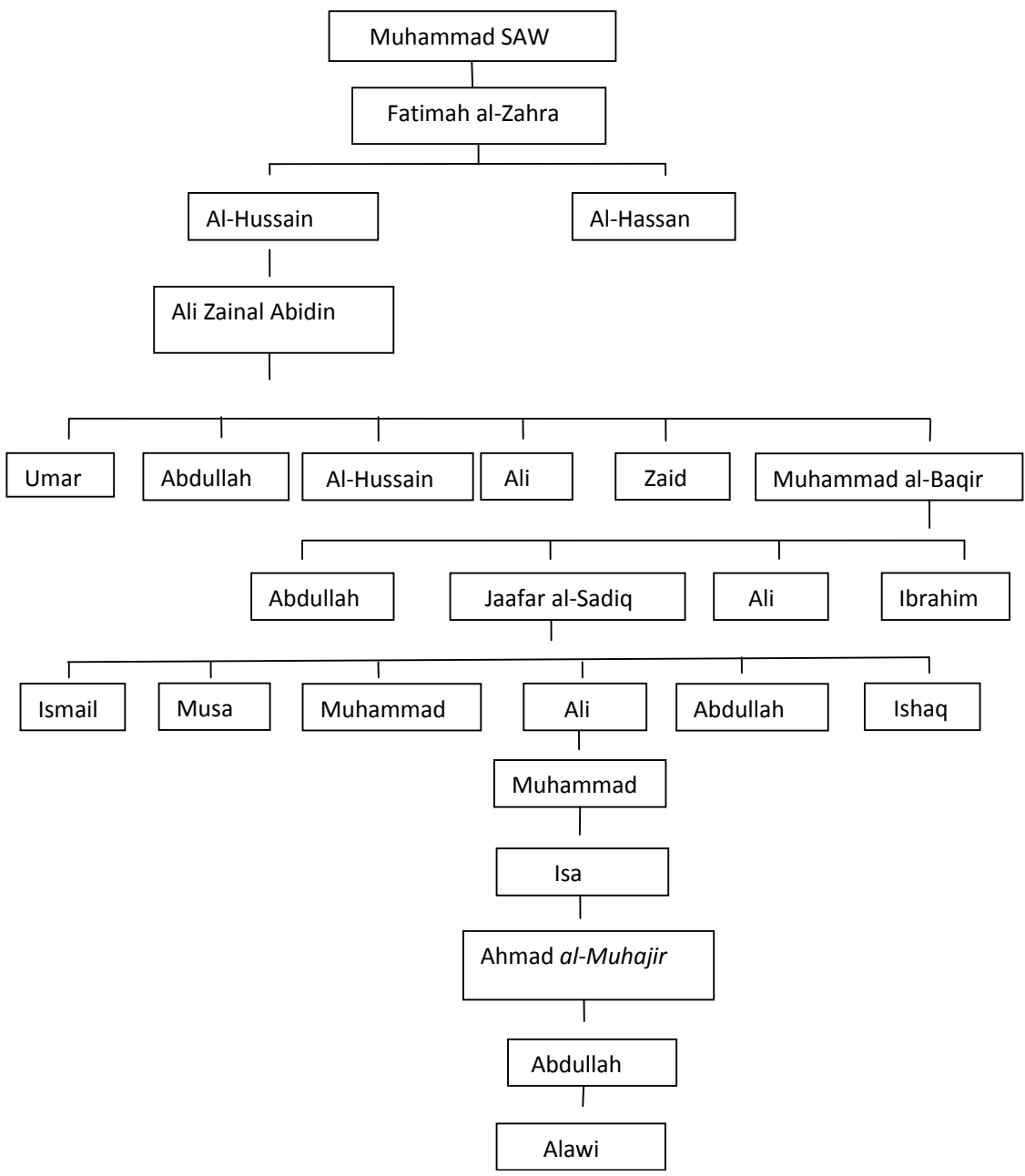

Source: Modified from R.O. Winstedt, "The Hadhramaut Saiyids of Perak and Siak", Journal of the Straits Branch of the Royal Asiatic Society, Vol. 79, September 1918; Mahayuddin Haji Yahaya, "Latarbelakang Sejarah Keturunan Sayid di Malaysia", Tamadun Islam di Malaysia, Kuala Lumpur: Persatuan Sejarah Malaysia, 1980, pp. 64-6. 
which secured them a special place and status in the Malay society. They became the source of reference for fellow Muslims in matters related to religion. In terms of relationship, there is a little gap between the Hadhramis and Malays. According to W. Linehan, the Sadah were more welcomed and free in their contacts with the royalties and aristocrats compared to the Malays. Malays respected the Sadah as much as they respected their sultans and rulers. ${ }^{15}$

In the Malay society, there are certain titles used to address respected people. The Sadah also received a special title by the Malays. In Pahang, especially in Kuala Tekal, Malays would call them engku and in Pekan and other districts they are called habib, tuan or tuan sayyid. In Terengganu, they are called Tukku or Tokku. While among themselves they would use word ana and anta which means I and you. ${ }^{16}$ Besides the title sayyid they are also called sharif and habib. There is another honorific title used in Hadhramaut to refer to the people of the high dignitaries of religion in society. It is normally given to teachers, scholars and men of religion that forms a group of noble men in Hadhramaut, Yemen and they are known as shaykh or mashaikh (plural). ${ }^{17}$ In Malaya, there is another group of Arabs known as shaykh or mashaikh who came not only to trade but also actively did the missionary works propagating and spreading Islam. ${ }^{18}$

\section{The Settlement of the Hadhrami Arabs}

The Hadhramis were scattered in almost every state in Malaya during the period of the nineteenth and twentieth century. However, the number of the Hadhramis in Malaya before that time could not be ascertained. Most of the available records were collected during the British colonial rule. Unfortunately, the censuses carried out in Malaya at that time did not classify the Arab population by clan, but rather the Arabs in general, regardless of their country origin. Therefore, it is difficult to decide the exact number of the Hadhramis in Malaya since their arrival in the country. Moreover, many of the Hadhramis in Malaya were those of Peranakan Arabs, a new generation of the Arab that mostly born out of the Hadhrami fathers with local women.

Most of the researchers and scholars in the field recorded that the majority of the Arabs in Malaya were from Hadhramut, Yemen. There is no way for this study to ignore these censuses as these are the only available records to trace the number of the Arab population in Malaya. These censuses are important to support the research done in order to facilitate the study. Since many of the Hadhramis in Malaya were those coming from Indonesia, (a lot of its foreign population of Arabs were Hadhramis from Hadhramaut, Yemen) apart from direct 
migration from Hadhramaut, this would suggest that the Hadhramis in Malaya were also of Hadhramaut origin. Furthermore, it is apparent in their surnames that they are descendants of the Prophet Muhammad S.A.W from Hadhramaut, Yemen. Practically, the Hadramis were easily recognized by the public as their names were bound with title sayyid. ${ }^{19}$

The earliest census on Malaya was carried out in 1871 on the Straits Settlements population of Singapore, Malacca and Penang. From this record it shows that the total number of Arabs was 1122. ${ }^{20}$ Many of them were concentrated in Singapore with 465 people followed by Penang 354 and Malacca 303. Out of 1122, 605 were males and the rest 517 were females. The Singapore Chronicle record shows that in 1830, the number of Arab population was 28 out of the total population of the island 20,243. ${ }^{21}$ Based on the Earl's account, the number of Arab population in Singapore in 1833 was 96. All of them were males. ${ }^{22}$ Further census was conducted in 1881 in the Straits Settlements saw the increase of Arab population in the three states. In ten years time their number had increased to 1637 with additional 515. However, the 1891 census showed a decrease with 1468 souls. The number slightly decreased in comparison with the 1881 census from every state. (Refer to Table 1.)

Whilst in the Federated Malay States, the 1891 census showed that their number was 427 with Pahang the mostly populated with 329 followed by Selangor with 27, Negeri Sembilan 20 and Perak 51 respectively. The 1901 census carried out in Federated Malay States showed the growth of the Arab population from the previous ten years with 574 in 1901. In the states of Negeri Sembilan, Selangor and Perak, the number of increment was quite small compared to Pahang that saw a significant rise from 329 in 1891 to 447 in 1901.

Table 1: Censuses of Arab Population in Straits Settlements (Singapore, Malacca and Penang)

\begin{tabular}{|c|c|c|c|}
\hline \multirow{2}{*}{ Year } & \multicolumn{3}{|c|}{ States/ Number of Arabs } \\
\cline { 2 - 4 } & Singapore & Malacca & Penang \\
\hline 1871 & 465 & 303 & 354 \\
\hline 1881 & 836 & 220 & 574 \\
\hline 1891 & 806 & 95 & 567 \\
\hline 1901 & 919 & 45 & 542 \\
\hline 1911 & 1237 & 135 & 702 \\
\hline 1921 & 1282 & 56 & 520 \\
\hline 1931 & 1939 & 88 & 605 \\
\hline
\end{tabular}

Source: Straits Settlements: Report on the Census of the Straits Settlements, taken on the $5^{\text {th }}$ April 1891, by E.M. Merewether, Eso, Singapore: Printed at the Government Printing Office, 1892. 
In 1911 the number of the Arabs population in Federated Malay States decreased from 574 to 337. However, their number increased to 656 in the 1921 census with Pahang 395, Selangor 82, Negeri Sembilan 78, and Perak 101. Their number again decreased to 402 in 1931. ${ }^{23}$ (Refer to Table 2)

During the last quarter of the nineteenth century Malaya, There were Hadhrami entrepreneurs reported to have applied license to open land for agricultural, mining as well as timber activities from the government of the State of Pahang. For example in 1890, Sayyid Hassan was awarded land for mining gold by the Sultan of Pahang. ${ }^{24}$ Sayid Hassan also had a good relationship with the Sultan of Pahang, Sultan Ahmad from which he was awarded other 14,000 acres of land stretching from Kuala Pahang to Air Hitam for agricultural purposes for 99 years. ${ }^{25}$ In 1921, Sayyid Mohamed Alwi al-Haddad together with his partner Ungku Abdul Rahman Ungku Abdul Majid applied for a mining license to extract gold in the area of about 2,000 acres in the District of Batu Talam, Raub, Pahang. ${ }^{26}$ The Al-Sagoff and Co. was also involved in paper production in Pahang. ${ }^{27}$ This possibly attracted fellow Hadhramis to move to Pahang to work there. Based on the censuses, it is found that since the first census carried out in 1871, the Arabs, mostly the Hadhramis were found scattered in almost every state in Malaya.

Table 2: Censuses of Arab Population in Federated Malay States

\begin{tabular}{|c|c|c|c|c|}
\hline \multirow{2}{*}{ Year } & \multicolumn{4}{|c|}{ States } \\
\cline { 2 - 5 } & Pahang & Selangor & N. Sembilan & Perak \\
\hline 1891 & 329 & 27 & 20 & 51 \\
\hline 1901 & 447 & 31 & 27 & 69 \\
\hline 1911 & 152 & 73 & 62 & 50 \\
\hline 1921 & 395 & 82 & 78 & 101 \\
\hline 1931 & 189 & 70 & 88 & 55 \\
\hline
\end{tabular}

Source: Federated Malay States, Census of the Population, 1901, Straits Settlement Population 1871, J.A.E. Morley, “The Arabs of the Eastern Trade”, p. 175, Federated Malay States Statistics 1906, Census Taken on $1^{\text {st }}$ March, 1901, Colonial Office Library, pp. 84-85, CO 575/3.

From the 1911 census done in the State of Kedah and Perlis, it showed that the number of Arabs was 119 and 10 respectively. From the report on the censuses of Kedah and Perlis for the year 1911, it is found from Tables III and IV on races and languages, that the Arabs are classified as Malays. ${ }^{28}$ "The large majority of the Arabs were practically Malays of remote Arab descent. The Syeds had usually described themselves as Arabs" ${ }^{29}$ This could probably refer to the spoken language where many of them could converse in Malay fluently. It is found that intermarriage between different races was common in Kedah and Perlis 
and their descendants learned to speak foreign languages aside from their mother tongue.

Table 3: Censuses of Arab Population in Non-Federated Malay States

\begin{tabular}{|c|c|c|c|c|c|}
\hline \multirow{2}{*}{ Year } & \multicolumn{5}{|c|}{ States } \\
\cline { 2 - 6 } & Johor & Terengganu & Kelantan & Kedah & Perlis \\
\hline 1911 & 699 & 186 & 17 & 119 & 10 \\
\hline 1921 & 736 & 567 & 118 & 226 & 154 \\
\hline 1931 & 1345 & 89 & 213 & 113 & 143 \\
\hline
\end{tabular}

Source: J.E. Nathan, The Census of British Malaya 1921, London, Dunstable and Watford: Printed by Waterlow \& Sons Limited, 1922, p. 92; Mahayudin Haji Yahaya, Sejarah Penempatan Orang Arab di Johor, Seminar Sejarah Budaya Johor Tahun 2000, Johor Bahru, Vol. 2, 2000, p. 4.

The majority of the Arabs born in Malaya of Malay mothers speak the Malay language. Many of them cannot speak fluent Arabic, but some can understand it. Due to the assimilation with the local people they easily adapted to the Malay culture and ways of life, including language, food, customs and fashions that eventually they could be called Malays. (Refer to Table 3) It shows that the Hadhramis in Kedah and Perlis were categorized under Malay race due to their spoken language, Malay. Furthermore, due to the assimilation with the locals and mix-marriage, their young generation has become Malays socially and culturally despite of their Arab blood. ${ }^{30}$

In the state of Johor, Onn Jaafar in his letter to the Medical Director Office in Johor on 31 January 1931, discussed about the issue of free medical treatment to the Arabs as enjoyed by the Malays. This is regarding a complaint made by Sayyid Omar and Sharifah Esah Hussein from Muar to the government asking for free medical treatment at the General Hospital Muar. In this matter Onn Jaafar considered Hadhramis as equal as the Malays and they were to be treated and considered as Malays. ${ }^{31}$

\section{The Distribution of the Hadhrami Arabs}

The Hadhramis travelled to many foreign countries looking for better living. Their colonies were to be found in many places, including in East Africa, India and in the Malay World. There were several factors that contributed to their emigration overseas, particularly to Malaya and the Malay Archipelago. The nineteenth century geopolitical and economic situation in Hadhramaut had forced the bulk of its population, especially the young to consider migrating to foreign lands. The internal skirmishes and uprisings against the Turk army had worsened the situation with a security crash in Hadhramaut. ${ }^{32}$ 
Hadhramaut also suffered from drought, terrible famine and constant tribal wars that made life risky and miserable. This encouraged many of them to move overseas as a solution to seek for a better source of income and living in foreign countries. ${ }^{33}$ The Hadhramis of Sadah clan were among those Arabs who migrated to the East and many of them were to be found in Dutch East Indies, Singapore and Malaya. When Penang and Singapore were opened by the British in the eighteenth and nineteenth centuries as free ports, the Hadhramis were among the earliest immigrants to settle in the islands. They came as traders and religious teachers. Therefore, the links between Arab countries and Malaya resumed. ${ }^{34}$

After the opening of the Suez Canal in 1869, travels by steam ships became popular and faster compared to traditional ships. This made the movement of ships as well as immigrants were easier, faster and their number also increased from time to time. The Arab Diaspora also spread faster to foreign lands of Indian, African and also in the Southeast Asia region including Malaya. ${ }^{35}$ In Malaya, there were many Hadhrami families of 'Alawiyyah descendants, such as al-Attas, alSaqqaf, al-Junied and al-Kaff. Many of these Hadhrami families were big names in the society. They were actively involved in business and became successful entrepreneurs and businessmen. When Singapore was opened by Stamford Raffles in 1819, the Hadhramis were among the earliest merchants who came to trade there. Sayyid Mohammad bin Harun al-Junied and his nephew Sayyid Omar bin Ali al-Junied came to Singapore in 1819. It was said that they were wealthy merchants from Palembang, Sumatra. ${ }^{36}$

Accordingly, the majority of the Hadhramis in Malaya were those who came from Hadhramaut, Yemen. They were the 'Alawiyyin, from the descendants of Sayyid Alawi, the grandson of Ahmad bin Isa al-Muhajir. According to Mahayudin Haji Yahaya, ${ }^{37}$ the Hadhramis migration to Malaya from Arabian Peninsula occurred in several stages that were directly and indirectly from the Arab Peninsula. He further noted that direct migration from the Arabian Peninsula rarely happened compared to indirect migration that involved the majority of the Arabs migrants from Hadhramaut to the Malay Archipelago. Most of them were those who came from the Arabian Peninsula through East Indies; Indonesia today. ${ }^{38}$

Omar Farouk discussed about Hadhramis' migration to Penang in which he mentioned that it began immediately after Francis Light took Penang from the Sultan of Kedah in 1786. ${ }^{39}$ This movement also involved migrated Hadhramis from neighbouring countries such as Aceh and Sumatera to Penang. Since Singapore was opened as a free 
port in 1819, it became a gateway to Penang to those Hadhramis from the Arabian Peninsula and also Hadhramis from East Indies to Penang. ${ }^{40}$

Singapore was the focal point and a place of attraction for the Hadhramis to invest their money and skills in trade and business ventures in Malaya. Since its opening as a free trade port by Raffles, the island managed to attract traders and merchants from all over the world. The al-Junieds were believed to be among the earliest Hadhramis to settle in the island when it was opened in 1819. Sayyid Muhammad bin Harun al-Junied arrived in Singapore in 1819 from Palembang, Sumatra. He was a Yemeni Arab who traded in Palembang. Sayyid Omar bin Ali al-Junied (1792-1852), the nephew of Sayyid Muhammad also came and joined him in Singapore in the same year. The Arab Street became the focal area to the Hadhramis in Singapore in the nineteenth century. They were actively involved in trading with India and the East Indies dominating spices and cloth trade. In Singapore, they were not only trading, but were also involved in real property business. ${ }^{41}$

\section{The Social Life of the Hadhrami Arabs}

In general, the Hadhrami society in Malaya was a mix-culture of Arab and Malay. Intermarriage between Hadhramis and local Malay women was common in the society. Since the Hadhrami migration involved vast numbers of Arab men, it was really rare to hear of the Arab female migration. Many of them did not bring along their families and they would leave their wives and children in the homeland in order to seek fortune and better living overseas. ${ }^{42}$

The Hadhramis were easily adapted to local customs and cultures and became part of the Malay community. Since Hadhrami community, especially the conservative and traditional Sadah families are so concerned about marriage and their lineage; parents would prefer to marry their daughters to Hadhrami men rather than to nonHadhramis. They only allow marriage amongst the Sadah families. ${ }^{43}$ In contrast to Hadhrami men, since Hadhramis are so concerned with the patriarchal lineage, the mix marriage between Hadhrami men and local women is common in the society. In the early period of their migration to the Malay World particularly in Malaya, many Hadhramis from Hadhramaut, Yemen married into the ruling class and royal families. Their credibility in religion and social status enabled them to be easily accepted by the Malays and were regarded as equal as to their rulers and aristocracy. Sayyid Abdul Rahman bin Sayyid Muhammad al-Idrus (1817 -1917) better known as Tukku Paloh who lived during the reign of Sultan Zainal Abidin III was married to Tengku Mandak, sister of Sultan Zainal Abidin III. ${ }^{44}$ 
Through marriage, the Hadhramis managed to acquire secured positions in the society. Their attachment with the royalties helped them a lot in getting social support from the ruling class as well as in their business enterprise. An example of this is in Aceh, where there are Hadhramis who inherited the throne and become sultans ${ }^{45}$ and also in Malaya, the Sultanate of Terengganu and the State of Perlis where the Sayyid Jamālullail's family managed to run the state since the early nineteenth century until today. ${ }^{46}$ Through the close contact with the ruling class, the Hadhramis were also granted with a land of concession such as Sayyid Hassan al-Attas. He was granted with a Concession Land in Ketapang, Pahang and Sayyid Muhamad al-Saqqaf was granted with a concession land in Kukob, Johor. ${ }^{47}$

Today, many of the Hadhramis in Malaysia are losing their identity of Arabness to intermarriage. Their intermarriage with local women and intermingling with local people have gradually diminished their cultural identity that is commonly characterised by language and culture. This phenomenon occurred during the second and third generations of Arabs in Malaya from local mothers who do not speak Arabic. According to A. Rahman Tang Abdullah, who studied the Hadhrami society in Muar, Johor also noted that Hadhramis used to communicate with local people especially the Malays using Malay Arabic language, a mix of Malay Language and informal Arabic language that is also called bahasa Arab pasar. ${ }^{48}$

Most of the Hadhramis who married to the Malay women do not speak formal Arabic or do not speak Arabic at all. The spoken language at home was Malay Arabic language, a mix of Malay and informal Arabic language which also called bahasa Arab pasar. They only taught their children to recite Qur'an at home. This was one of the reasons why the young generations of born Arabs in Malaya could not speak Arabic. However, According to Omar Farouk, most of the Hadhramis in Penang were familiar with the Arabic language; it just the matter of they can speak it or not. The majority of the Hadhrami parents in Penang sent their children to English medium schools and English became a common language to younger generations compared to Arabic. ${ }^{49}$

Most of the children only received formal education at the school learning Malay and English. Arabic was only taught at madrasah and it became medium of instruction in almost all madrasahs in Malaya. Though in the early days, the early generations of wealthy hadhramis and those who could afford would send their children, especially boys to be educated in the homeland, Hadhramaut. They were taught Arabic language as well as religious knowledge..$^{50}$ Malay was also a common language in Hadhramaut. It was also widely spoken and became 
a mother tongue of the children of born Arab from mixed blood of hadhramis with Malay or Javanese women. ${ }^{51}$

Although J.E. Nathan's survey was done in 1921 and A. Rahman Tang Abdullah's work was carried out in 1991/92, this issue has long been noticed in a survey of census done in Malaya in the state of Kedah and Perlis in the year 1911. Since the report was based on languages and races, it indirectly has categorized Arabs as Malays. This census shows that the majority of the hadhramis in Kedah and Perlis have become part of the Malay community. They speak Malay and married to local women. The children of the hadhramis born in Malaya of Malay mother, the Peranakan Arab also speaks Malay. Moreover, they also have adapted to the Malay way of life socially and culturally so no doubt they can be called Malays. ${ }^{52}$

The Hadhramis were so concerned about their family genealogy. In order to ensure the family ties were safely guarded, they would record marriages, birth and death of the family members. In Malaya, the Hadhrami society known as Rabitah al-'Arabiyyah based in Singapore was responsible for keeping records of Hadhrami descendants in the country. They have representatives who record every birth, marriage and death within Sadah families. ${ }^{53}$ The science of genealogy or nasab or also known as Ilmu Salasilah is much stressed by the older generations of the Hadhrami Sadah. ${ }^{54}$

However, in the 1920s and 1930s, there was a conflict between the Malays and the Hadhramis, where the Malays started to feel that they were being neglected by their Muslim Arab brothers. There were Hadhramis who confined to their elitist and exclusive lifestyles separated from the Malays abandoned the cause of the Malays for their own interests, created an atmosphere of distrust between them. The Malays began to question the Hadhramis' sincerity in religious and social responsibilities towards their fellow brothers in Islam. Syed Muhd Khairudin Al-Junied stresses on the issues that worried the Malays regarding the roles that should be played by the Hadhrami Arabs, in which they hoped that it should be focused on improving the society (Malay Society), particularly on the economy and not to take control over their lives. The Malays also felt that they were being left behind compared to their fellow brothers (Hadhramis). As a result, this dissatisfaction led to the establishment of an organization known as Kesatuan Melayu Singapura (KMS) or Singapore Malay Union in 1926. ${ }^{55}$ KMS believed that only the Malay Muslims should be the representative of the Malay community and its membership should be restricted to the native Malays only. ${ }^{56}$

The Malays also printed their own newspaper Utusan Melayu in 1939 as a tool to voice out their opinions, and at the same time, 
proclaimed that Warta Malaya that was published by the Al-Saqqaf family did not represent the views and opinions of the Malays. This situation impinged the Hadhrami Arabs' reputation in the publishing industry in Malaya. ${ }^{57}$ Then, emerged a new categorisation of Muslims in Malaya based on their ethnic and race, such as Darah Keturunan Arab (DKA) and Darah Keturunan Keling (DKK), in order to differentiate them from the pure Malays. ${ }^{58}$

Abdul Rahim Kajai was one of the influential journalists during his time (1940) was known to have highlighted the term bangsa, in which he says that Islam is "not a bangsa" and further reminds "religious leaders that Malay unity must not be neglected in favour of the bonds of Islam". Abdul Rahim Kajai cynically referred to the Malays born of mixed ethnic origin with Arab blood; the Peranakan Arab as Darah Keturunan Arab (DKA), and those with Indian blood as Darah Keturunan Keling (DKK). ${ }^{59}$ This situation affected the social relationship of both communities and it also led to social isolation and adverse effect to the Malays - Peranakan Arabs relationship.

\section{Conclusion}

The Hadhramis in Malaya managed to adapt to the Malay culture and way of life. They easily adapted to the Malaya culture and way of life that enabled them to mingle in the society and eventually become part of the Malay community. The mix marriage between and among the hadhramis and local women gave birth to a new generation of Arab Peranakan. The hadhramis had the tendency to marry into leading families, from which they would benefit from the marital bond to gain social, economic and political prestige. Many of them managed to secure good positions and status in the Malay society. Some of them have become successful traders as well as entrepreneurs. While, some others have attained the highest level of social life, becoming part of the ruling class in the country like the Jamalullail's in Perlis.

Despite their small number, the Hadhrami community in Malaya had played a considerable role in bringing about change in the society through their contribution in religion and economy. The land that was once foreign to them as a sojourn destination has now become the motherland to the young generations of Peranakan Arab in Malaya. In fact, based on the federal constitution as stated under article 160, the Hadhrami Arabs in Malaya are eligible to be called Malays. The Hadhramis benefitted from the social status and privileged attained in the Malay society. Therefore, being a minority group of immigrants did not forbid the Hadhramis from prospering in Malaya. They consolidated 
their social, economic and political networking that enabled them to survive in Malaya among the Malay community.

\section{Notes}

1 According to J.A.E. Morley, the long distance maritime trade had long been established between seaports of Arabia, East Africa, India, Ceylon, East Indies and China. These seaports were connected to each other by the sea trade link following the changes of monsoon. This shows that the Arabs were familiar with the sea route of the Indian Ocean to China including the Malay Archipelago's. J.A E. Morley, "The Arabs and the Eastern Trade", Journal of Malayan Branch of Royal Asiatic Society (JMBRAS), Vol. 22, no. 1, 1949, p. 143. The Arab settlements were to be found in Canton, China around the $2^{\text {nd }}$ century A.D. See S. M. Imamuddin, "Arab Mariners and Islam in China", Journal of the Pakistan Historical Society, (ed.), S. Moinul Haq, Vol. 32, no. 3, July, 1948, pp. 168-170.

2 Affan Seljuq, "Some Muslim Geographers on South-East Asia", Journal of The Pakistan Historical Society, Vol. 37, no. 2, April, 1989, p. 129.

$3 \quad$ S.M. Yusuf, "The Route of Arab Mariners Through al-Zabaj (Further India) in the Third and Fourth Centuries $\mathrm{H}^{\prime \prime}$, in Studies in Islamic History and Culture, Delhi: Adam Publishers \& Distributors, 1989, p. 132. During this period of time $\left(9^{\text {th }}-10^{\text {th }}\right.$ centuries $)$, Arabs' navigation was at its peak. They had travelled past the Indian Ocean and went up to China passing the al-Zabaj (further India). In due course they sailed passing the Malay Archipelago.

4 J.A.E. Morley, "The Arabs and the Eastern Trade", p. 15

5 R.B. Serjeant, "The Saiyids of Hadhramaut", Studies in Arabian History and Civilisation, London: Variorum Reprints, 1981, p. 24. See also Mahayudin Haji Yahaya, Sejarah Orang Syed di Pahang, Kuala Lumpur: Dewan Bahasa dan Pustaka, 1984, p. 27.

6 Abdul Ali, “The Arabs as Seafarers", Islamic Culture, Vol. 54, no. 4, October, 1980, p. 211.

7 R.B. Serjeant, “The Saiyids of Hadhramaut”, pp. 24-25.See also Mahayudin Haji Yahaya, Sejarah Orang Syed di Pahang, p. 27

8 "Penzance's" Report of Proceeding for Month of March, 1933. Narrative of a Visit to the Wadi Hadramaut, Enclosure No. 2 to p. 4, CO 273/551/16; Omar Farouk Shaeik Ahmad, "The Arabs in Penang", Malaysia in History, Kuala Lumpur: Malaysian Historical Society, Vol. 21, no. 2, 1978, p. 2.

$9 \quad$ Syed Muhammad Naquib al-Attas, Historical Fact and Fiction, Johor: Penerbit UTM Press, 2011, p. 130.

10 The same approach was taken by Francis Light when he took Penang that was later on called Province of Wellesley in 1786. Light introduced a policy that attracted many foreign traders to trade in Penang. Duty free was exempted upon traders and merchants as well as freedom of acquiring land in Penang that had attracted many foreign merchants and traders including those from Hadhramaut, Yemen, India, as well as people of Malaya to settle there. Police force was also established to look after the 
safety and security of the island. See National Archive Malaysia (Kuala Lumpur): MISC. 19/1 ANM.

11 Mahyuddin Haji Yahaya, "Latarbelakang Sejarah Keturunan Sayid di Malaysia", Tamadun Islam di Malaysia, Kuala Lumpur: Persatuan Sejarah Malaysia, 1980, pp. 64-6, W.H. Ingrams, Aden Protectorate, A Report on the Social, Economic and Political Condition of the Hadramaut, London: Printed and Published by His Majesty's Stationery Office, 1936, pp. 36-39. Colonial No. 123.

12 Ahmad bin Isa, the al-Muhajir (the traveller) was the great grandson of Ali al-Qaim bil Basrah. Ali al-Qaim bil Basrah was the great-grandson of Hussain, the grandson of Prophet Muhammad SAW. Ahmad bin Isa migrated from Basra to Hadhramaut around 512 A.H./1127 A.D. As claimed, they were the descent of Prophet Muhammad SAW. "Penzance's" Report of Proceeding for Month of April, 1933, Narrative of a Visit to the Wadi Hadhramaut, Public Record Office, London (PRO), Colonial Office (CO) $273 / 551 / 16$.

13 R.O. Winstedt, "The Hadhramaut Saiyids of Perak and Siak", Journal of the Straits Branch of the Royal Asiatic Society, Vol. 79, September, 1918. According to Ibn Hazm, a famous historian in the $5^{\text {th }}$ A.H/11 A.D, he recorded in Jamharah Ansab al-Arab genealogy of the Prophet Muhammad SAW's progeny through his grandsons Hassan and Hussain. However, the record of the family ends at the sixth generation of the family. It is said that there had been confusion on the genealogy of Prophet Muhammad SAW since there were fake laims made by irresponsible person. However, the historiography of the genealogy of the Prophet Muhammad SAW based on the Hadrami Sayyids's sources resumed after $10^{\text {th }}$ century A.H/ $16^{\text {th }}$ century A.D. See Jamharah Ansab Al-Arab Li Abi Muhammad 'Ali bin Ahmad bin Said bin Hazm Al-Andalus 384-456, Abd Al-Salam Muhammad Harun (Tahqiq wa Ta'liq), Cairo: Dar Al-Ma'arif, 1962M/1382H, 39-59. W.H. Ingrams, Aden Protectorate, A report, pp. 36-8. W. Linehan, "A History of Pahang", JMBRAS, Vol. 14, no. 2, May 1936, p. 81. Mahayudin Haji Yahaya, "Sejarah Orang Syed di Pahang”, p. 88. Ibid., p. 694; See also W.H. Ingrams, Aden Protectorate: A Report, pp. 40-41. Syed Ali bin Mohamed al-Attas, Allahyarham Syed Hassan bin Ahmad alAttas Seorang Mujahid dan Pembangunan Ummah, Johor: Madrasah al-Attas al-Arabiah Johor, 1998, p. 6. L.W.C. van den berg, Orang Arab di Nusantara (trans.), Rahayu Hidayat, Jakarta: Komunitas Bambu, 2010, p. 33. Straits Settlement Population 1871, Microfilm no. 242.

$21 \quad$ Singapore Chronicle, No. 165, Thursday 15 July 1830. G.W. Earl, The Eastern Seas, with an Introduction from C.M. Turnbull, Singapore: Oxford University Press, 1971, p. 362.

23 Federated Malay States, Census of the Population, 1901, Compiled by George Thompson Hare, Published by Command, Colonial Office Library, 
1902. See also PRO, CO 575/3, Federated Malay States Statistics 1906, Census Taken on $1^{\text {st }}$ March, 1901, Colonial Office Library, pp. 84-5.

Aminudin bin Abd. Rashid, Syed Hassan bin Ahmad al-Attas: Satu Kajian Biografi, B.A. Thesis, University of Malaya, 1995/6, p. 48.

Sultan Pahang 33/1916, National Archive, Malaysia, Kuala Trengganu Branch, 1306AH/1888AD.

Letter from District Officer of Raub, Pahang on $14^{\text {th }}$ March 1921 to the District Officer, Johor Bahru regarding the application of Ungku Abdul Rahman Ungku Abdul Majid from Bukit Taram, Johore, and Sayyid Mohamed bin Alwi al-Haddad for a prospecting license over 2000 acres of Land in the Mukim of Batu Talam, Raub, Pahang, CLM 363/1921, See Letter from Al-Sagoff and Co., to District Office of Kuantan on 31 October 1923. DOK 509/1923.

Report on the Census of Kedah and Perlis A.H 1329 (A.D 1911), Penang: Printed at the Criterion Press Ltd. 1911. Colonial Office, 10 $0^{\text {th }}$ March, 1911, Straits Settlements: Report on the Census of the Straits Settlements, taken on the $5^{\text {th }}$ April 1891.

Ibid., p.7.

Report on the Census of Kedah and Perlis A.H 1329 (A.D 1911), 7.

See a letter sent by Onn Jaafar to Medical Director Office of Johor Bahru, Johore on 31 January 1940, GA 27/1940.

W.H. Ingrams, Aden Protectorate: A Report, pp. 29-36.

Besides earning more income and had better life in Malaya, where many of them married and settled there but they never forget to send home remittances every year. With this money they supported lives of the relatives, building houses, mosques, schools etc. Many of them became successful traders in Malaya. This practice continued until the World War II broke out in 1942 when Malaya was attacked by Japanese army. Many of them became successful traders in Malaya.

In fact the relationship between Malaya and the Arab countries had existed ever since the early decades of the Islamic Era and even prior to the advent of Islam. The Trans ocean business venture between the East and the West had long been established. Arab merchants crossed the Indian Ocean to the Far East passing the Malay Archipelago on the South China Sea to China Ocean to get to China. While plying forth and back to the East, Arab merchants became acquainted with the Malay World and became aware of its development. Some of them stopped at these islands and build settlements. Their existence were to be found in several areas in the region such as in East Indies, Malaya, Singapore, Borneo and in Philippines. In the early times they were focused in trade ports such as in Aceh, Malacca and Singapore. The Arabs lost supremacy over the trade venture in the East when European powers started dominating the maritime trade in the East in the sixteenth century. This incident had indirectly slackened the relationship between the Arabs and the Malay World, especially Malaya. When Penang was taken by Francis Light in 1786, and declared it as British colony, this had attracted foreign traders to trade in Penang. Arabs were among the earliest settlers in Penang. The 
opening of Singapore by British in the $19^{\text {th }}$ century was also seen as a link to the Arab-Malay connection. Hence, the ties between Arab countries and Malaya resumed.

Peter G. Riddell, "Religious Links Between Hadhramaut and the The Malay-Indonesian World, C. 1850 to C. 1950", in Ulrike Freitag \& W.G. Clarence-Smith, Hadrami Traders, Scholars, and Statemen in the Indian Ocean, 1750s - 1960s, Leiden;New York;Koln :Brill, 1997, p. 221,

Ameen Ali Talib, "Hadramis in Singapore", Journal of Muslim Minority Affairs, Vol. 17, no. 1, 1997, p. 89. Mahayudin Haji Yahaya, Sejarah Penempatan Orang Arab di Johor, p. 1, See also Mahayudin Haji Yahaya, Sejarah Orang Syed di Pahang. According to Serjeant, R.B, the Hadhramaut Sayyids were said to arrive in East Indies just some time before the coming of the Dutch to the island in the $18^{\text {th }}$ century. However, this statement could still be argued. They could have come to the East Indies earlier than the $18^{\text {th }}$ century. Records from the travel's accounts of Ibnu Battuta and Marco Polo had shown that Islam came to the region since the very beginning of the $13^{\text {th }}$ century. Even during the glory period of Malacca in the $15^{\text {th }}$ century, there were Arab merchants from the Arab countries trading in Malacca. And these traders would stop at East Indies islands such as Perlak and Pasai for the monsoon change before sailing back to their countries. R.B. Serjeant, "The Saiyids of Hadramawt", pp. 24-5. See Omar Farouk Shaeik Ahmad, "The Arabs in Penang", pp. 2-10. It is believed that what attracted Arab people to come to Penang during that time was the trade policy introduced by Francis Light that charged no import duties to merchants and also the freedom of right to new settlers of acquiring land in Penang. Please see R.O Winstedt, A History of Malaya, Singapore: Marican, 1962, p. 210.

41 National Heritage Board, Singapore, the Encyclopedia, Singapore: Editions Didier Millet, 2006, p. 28.

42 However, they would constantly send money back home and once they accumulated enough, they would return home for good. Enclosure No. 2 to Penzance's Report of Proceedings for Month of March 1933, Narrative of A Visit to the Wadi Hadramaut. PRO, FO 371/16852. Political Eastern Arabia. Omar Farouk Shaeik Ahmad, "The Arabs in Penang", p. 3.

44 Mohamad Abu Bakar, "Ulama dan Umara: Tok Ku Paluh dan Pemerintahan Islam", in Muhammad Abu Bakar, Ulama Terengganu Suatu Sorotan, Terengganu: Utusan Publications \& Distributors Sdn. Bhd, 1991, p. 83.

Cesar Adib Majul, Theories on the Introduction and Expansion of Islam in Malaysia, Philippines: Siliman University, 1964, p. 349.

46 Julie Tang Su Chin, Sejarah Kerajaan Perlis 1841-1957, Malayan Branch of the Royal Asiatic Society (MBRAS), Monograph No. 32, 2002.

47 Alsagoff Concession Kukup, 15 March 1906, J/Pelb., National Archive, Malaysia (Johor Bahru Branch), See also Saadiah Said, Kegiatan Keluarga al- 
Sagoff Dalam Ekonomi Johor 1878-1926, B.A Thesis, Universiti Kebangsaan Malaysia, 1979, p. 53.

A. Rahman Tang Abdullah, Sejarah Masyarakat Keturunan Arab di Muar, Academic Exercise, Department of History, Faculty of Arts and Social Sciences, University of Malaya, 1991/92, p. 53.

50 J.A.E. Morley, "The Arabs and the Eastern Trade", pp. 145, 168.

51 W.H. Ingrams, Aden Protectorate: A Report, p. 12.

52 Report on the Census of Kedah and Perlis A.H 1329 (A.D 1911), 7.

53 In Indonesia, there is a board of Hadhrami Sayyid society known as Rabitah al-Alawiyyah that is based in Jakarta keeping records of the Ha $\square$ rami descendants. It also has a branch in Singapore. The society was formed in 1927 and it was known as The Alawi Union. See Natalie Mobini-Kesheh, The Hadrami Awakening: Community and Identity in the Netherlands East Indies, 1900-1942, New York: Southeast Asia Program Publications, 1999, p. 99.

54 Sy. Aliedin, "Pengantar Singkat Ilmu Nasab", paper presented at the Seminar Diaspora Arab Nusantara: Peranan dan Sumbangan, Lembaga Muzium Negeri Kedah dan Perbadanan Perpustakaan Awam Kedah, Wisma Darul Aman Alor Setar, Kedah, 2011, 5 - 7 Mac. Syed Muhd Khairudin Aljuneid, "The Role of Hadramis in Post-Second World War Singapore - A Reinterpretation", Immigrants \& Minorities, 2007, http:/ / dx.doi.org/10.1080/02619280802018165. William R. Roff, The Origins of Malay Nationalism, Kuala Lumpur and Singapore: University of Malay Press, New Haven and London: Yale University Press, 1967, pp. 190-191. Syed Muhd Khairudin Aljuneid, "The Role of Hadramis in Post-Second World War Singapore...". Kingdom: Cambridge University Press, 2002, pp. 270. 